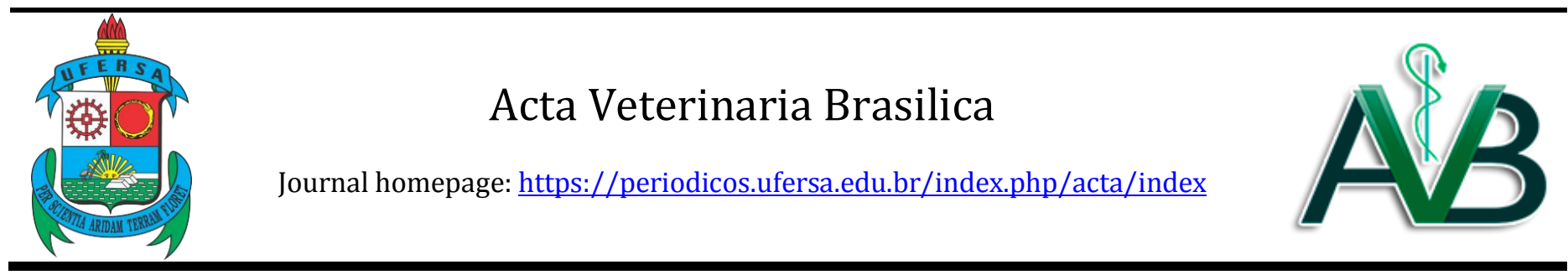

Original Article

\title{
Etiology and in vitro antimicrobial susceptibility profile of strains isolated from bovine mastitis in dairy herds from the midwest region of Santa Catarina state, Brazil
}

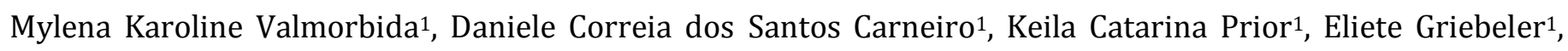
Marcella Zampoli Troncarelli'i, Diogenes Dezen ${ }^{1}$

${ }^{1}$ Laboratório de Microbiologia Veterinária, Instituto Federal Catarinense, Concórdia - SC, Brasil.

\section{A R T I C L E I N F O}

Article history

Received 15 August 2017

Received in revised form 10 September 2017

Accepted 26 September 2017

Keywords:

Staphylococci

Streptococci

Corynebacterium spp.

Animal health

Dairy cattle

\begin{abstract}
A B S T R A C T
Dairy farming is an important social and economic activity in the Midwest region of Santa Catarina State, Brazil. However, despite technological advances in the productive chain, mastitis is still considered the main disease of dairy herds, due its high economic impact. Bacterial pathogens are the main cause of this disease and failures in the treatment of clinical cases are attributed in part to the antimicrobial resistance of these pathogens. As an alternative, in vitro antimicrobial susceptibility tests of strains isolated from bovine mastitis cases have been carried out; the information generated contributes to strategic treatment measures, and also to the control of microorganism resistance. Therefore, the aims of the present study were to evaluate the etiology and in vitro antimicrobial susceptibility profiles of bacterial strains isolated from cases of bovine mastitis in dairy herds from the Midwest region of Santa Catarina State, Brazil. For this purpose, 345 milk samples were collected from 70 herds located in 16 different municipalities. The main pathogens isolated were: staphylococci (55.9\%), streptococci (34.8\%), Corynebacterium spp. (7.8\%) and Escherichia coli (1.4\%). The resistance rates of staphylococcus strains to ampicillin and to gentamicin were lower (24.9\%) and higher (33\%), respectively, than those obtained in other Brazilian studies. The resistance profiles of streptococcus strains were similar to those described in the literature, while Corynebacterium spp., showed high resistance rates to tetracycline (85.2\%). Moreover, a considerable prevalence of staphylococcus $(27.5 \%)$ and streptococcus $(11.7 \%)$ multiresistant strains was verified. These data reinforce the need for regional characterization of microorganisms.
\end{abstract}

\section{INTRODUCTION}

Brazil has significant milk production, with 35 million tons of milk produced per year. Santa Catarina ranks fifth in milk production among the Brazilian states, where the Western region accounts for $75 \%$ of total production (IBGE/PPM 2015). These statistics highlight the economic and social impact of dairy activity in the region.

Despite technological advances in productivity, genetic quality and management of dairy herds, bovine mastitis still represents a major problem in the productive process. Mastitis is the most costly endemic disease of milk production in the world (HALASA et al., 2007). In Brazil, it is estimated that clinical or subclinical cases of mastitis lead to a 12 to $15 \%$ decrease in milk production (DIAS, 2007). Bacterial infections are the main cause of mastitis and the most common pathogens involved are staphylococci, streptococci, coliforms and Corynebacterium (MELLO et al., 2012; OLIVEIRA et al., 2011; PERSSON; NYMAN; GRÖNLUND-ANDERSSON et al., 2011). Therefore, antimicrobial drugs have been widely used for the treatment and control of the disease.

\footnotetext{
* Corresponding author: diogenes.dezen@ifc.edu.br
} 
However, the use of a single treatment protocol is a challenge, considering the multifactorial causes of mastitis and the occurrence of resistant bacterial strains to antimicrobial drugs (BRADLEY, 2002; ERSKINE et al., 2004).

Temporal trends of antimicrobial susceptibility of pathogens causing mastitis have been described in several countries. According to a retrospective study with 2,778 bacterial strains evaluated between the years 1994 and 2000, there was an increase in the number of ampicillin-, penicillin- and erythromycin-resistant $S$. aureus strains (ERSKINE et al., 2002). Antimicrobial resistance is not a recent phenomenon, but is currently a critical health problem. For many decades and at different levels, bacteria usually involved in common infections have experienced an artificial selection pressure due to the abusive use of antimicrobials. This has contributed to the persistence of genetically resistant bacterial subpopulations, even to newly developed drugs, which present a major public health challenge. With the scarcity of new antimicrobials arriving on the market, measures to prevent a global health crisis are urgently required (OMS, 2012).

As a control measure, the in vitro antimicrobial susceptibility profiles of bacterial strains isolated from cases of mastitis have been determined (PERSSON; NYMAN; GRÖNLUND-ANDERSSON et al., 2011; MARTINI et al., 2017; NADER FILHO et al., 2007; XU et al., 2015).
Information on the occurrence of resistance is not only required locally, but also regionally and internationally, to detect changes that require intervention strategies. In order to fulfill these requirements, continuous monitoring systems are needed to verify changes in the occurrence of resistance, thereby optimizing treatment strategies and controlling the increase in resistance of microorganisms to antimicrobials (AARESTRUP, 2004). In this regard, we evaluated the etiology and in vitro susceptibility profiles of bacterial strains isolated from cases of mastitis in dairy herds of the Midwest region of Santa Catarina State, Brazil, in order to contribute to prophylactic and control measures in these herds.

\section{MATERIALS AND METHODS}

The present study was previously approved by the ethics committee on the use of animals (CEUA) at the Catarinense Federal Institute - campus Concórdia, Brazil, under registration number 34/2015.

Three hundred and forty-five milk samples were collected from cows with clinical or subclinical mastitis. The animals were from 70 dairy herds located in 16 municipalities of Santa Catarina state: Alto Bela Vista, Arabutã, Capinzal, Concórdia, Descanso, Ipira, Irani, Jaborá, Lindóia do Sul, Modelo, Peritiba, Pinhalzinho, Ponte Serrada, Presidente Castelo Branco, Seara and Xavantina (Figure 01).

Figure 01 - Spatial distribution of the municipalities where the dairy herds were sampled. The numbers of samples collected per municipality were classified into categories, which are represented by different colors, as shown in the legend.

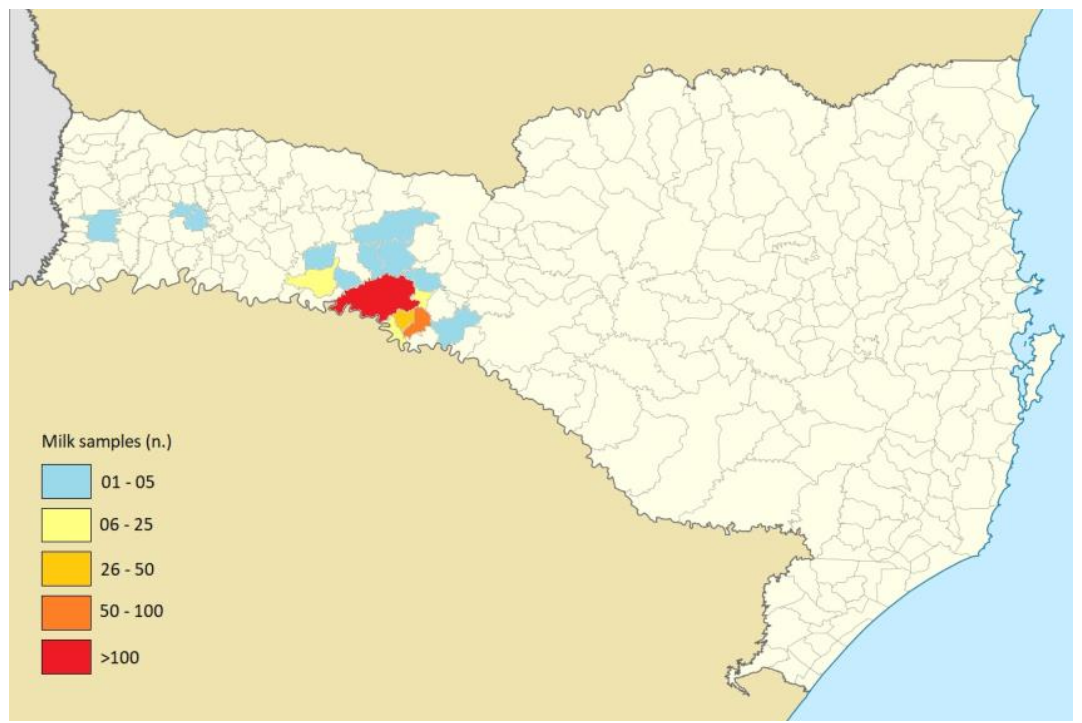

Source: Modified from https://commons.wikimedia.org/wiki/File:Brazil_Santa_Catarina_location_map.svg\#

Microbiological analyses were carried out at the Laboratory of Veterinary Microbiology at the Catarinense Federal Institute campus Concórdia. Aliquots of milk $(10 \mu \mathrm{L})$ were cultured in $5 \%$ Sheep Blood Agar and MacConkey Agar, followed by incubation at $37^{\circ} \mathrm{C}$ for 24 to 72 hours. The resulting growth of the culture was monitored every 24 hours. Identification of the colonies was performed according to their morphological, microscopic and biochemical characteristics (MARKEY et al., 2013). 
The antimicrobial susceptibility testing (AST) was carried out using the Kirby-Bauer disk-diffusion method (CLSI, 2012). Bacterial cultures of 18-24 hours were resuspended in saline solution to an equivalent turbidity of 0.5 McFarland standard. Using a sterile swab, the isolates were inoculated on Petri dishes containing
Mueller Hinton (MH) agar for cultures of staphylococci and Escherichia coli, or MH Blood agar for cultures of streptococci and Corynebacterium. Subsequently, disks impregnated with antimicrobial drugs were applied according to the pathogen tested (Table 1).

Table 1 - Antimicrobial drugs tested according to the isolated bacterial groups.

\begin{tabular}{|c|c|c|c|c|}
\hline Antimicrobial (concentration/disk) & Staphylococci & Streptococci & Corynebacterium spp. & E. coli \\
\hline Amikacin $(30 \mu \mathrm{g})$ & - & - & - & $\mathrm{X}$ \\
\hline Amoxacillin-clavulinic acid $(20 / 10 \mu \mathrm{g})$ & $\mathrm{X}$ & $\mathrm{X}$ & - & $\mathrm{X}$ \\
\hline Ampicillin $(10 \mu \mathrm{g})$ & $\mathrm{X}$ & $\mathrm{X}$ & - & $\mathrm{X}$ \\
\hline Cephalonium $(30 \mu \mathrm{g})$ & $\mathrm{X}$ & $\mathrm{X}$ & - & - \\
\hline Cephapirin $(30 \mu \mathrm{g})$ & $\mathrm{X}$ & $\mathrm{X}$ & - & - \\
\hline Cefuroxime $(30 \mu \mathrm{g})$ & $\mathrm{X}$ & & - & $\mathrm{X}$ \\
\hline Ciprofloxacin $(5 \mu \mathrm{g})$ & - & - & - & $\mathrm{X}$ \\
\hline Clindamycin $(2 \mu \mathrm{g})$ & $\mathrm{X}$ & $\mathrm{X}$ & $\mathrm{X}$ & - \\
\hline Erythromycin $(15 \mu \mathrm{g})$ & - & $\mathrm{X}$ & - & - \\
\hline Gentamicin $(10 \mu \mathrm{g})$ & $\mathrm{X}$ & - & $\mathrm{X}$ & $\mathrm{X}$ \\
\hline Levofloxacin $(5 \mu \mathrm{g})$ & - & - & - & $\mathrm{X}$ \\
\hline Trimethoprim-sulfamethoxazole $(25 \mu \mathrm{g})$ & $\mathrm{X}$ & - & - & $\mathrm{X}$ \\
\hline Tetracycline $(30 \mu \mathrm{g})$ & $\mathrm{X}$ & $\mathrm{X}$ & $\mathrm{X}$ & - \\
\hline
\end{tabular}

X: tested antimicrobial; -: not-tested antimicrobial.

After $18 \mathrm{~h}$ of incubation at $37^{\circ} \mathrm{C}$, the inhibition zone diameter $(\mathrm{mm})$ was measured and the samples were classified as resistant (R), susceptible (S) or intermediate (I). Strains that showed any degree of resistance (R or I) to three or more classes of antimicrobials were classified as multiresistant (SCHWARZ et al. 2010). For data analysis, descriptive statistics were used, according to the frequency distributions obtained in microbiological tests.

\section{RESULTS AND DISCUSSION}

Staphylococcus was the most frequently isolated genus in the evaluated milk samples (55.9\%) (Table 2). Staphylococcus aureus is still the most prevalent pathogen causing intramammary infections in dairy cattle worldwide (ABEBE et al., 2016; PETROVSKI et al., 2009; RIEKERINK et al., 2010; TAPONEN et al., 2017). In this study, the isolation rate for $S$. aureus was $40.3 \%$. In Brazil, others authors found similar frequencies, ranging from $8.3 \%$ to $57.8 \%$ (COSTA KREWER et al., 2015; MARTINS et al., 2010; MELLO et al., 2012; LAFFRANCHI et al., 2001; OLIVEIRA et al., 2011). Besides S. aureus, other species of Staphylococcus that were earlier considered of minor importance are now accepted as relevant human and animal pathogens (GUIMARÃES et al., 2016). In the present study, four species of coagulasenegative staphylococci were identified: $S$. haemolyticus, $S$. epidermidis, $S$. pasteuri and $S$. xylosus, which were previously detected in mastitis milk samples (FREY et al., 2013; GUIMARÃES et al., 2016; SOARES et al., 2012; XU et al., 2015). The results obtained reinforce the importance of these pathogens as mastitis causing agents in dairy herds of the Midwest region of Santa Catarina State, having a direct implication for infection control measures, since the correct identification of the etiological agent is fundamental to establishing appropriate prevention and control measures (HENNEKINNE et al., 2010).

Table 2 - Frequency of pathogens isolated from samples of bovine mastitis milk collected in dairy herds of the Midwest region of Santa Catarina state.

\begin{tabular}{lr}
\hline Etiological agent & n. (\%) \\
\hline Staphylococci & $193(55.9)$ \\
Staphylococcus aureus & $139(40.3)$ \\
Staphylococcus haemolyticus & $4(1.2)$ \\
Staphylococcus epidermidis & $2(0.6)$ \\
Staphylococcus pasteuri & $2(0.6)$ \\
Staphylococcus xylosus & $1(0.3)$ \\
Staphylococcus spp. & $45(13.0)$ \\
Streptococci & $120(34.8)$ \\
Streptococcus uberis & $75(21.7)$ \\
Streptococcus. dysgalatiae & $15(4.3)$ \\
Streptococcus agalactiae & $8(2.3)$ \\
Streptococcus spp. & $22(6.4)$ \\
Corynebacterium spp. & $27(7.8)$ \\
Escherichia coli & $5(1,4)$ \\
TOTAL & $345(100.0)$ \\
\hline
\end{tabular}

The isolated strains of staphylococci showed higher resistance rates to tetracycline, gentamicin, trimethoprim-sulfamethoxazole and ampicillin (Table 3). In cattle production systems, antimicrobials like gentamicin, tetracyclines and penicillins are widely used (ECONOMOU; GOUSIA, 2015) and in Brazil, many veterinary medicines are based on these active principles, including intramammary formulations (MARTINI et al., 2017). Furthermore, the genetic basis for staphylococcal resistance to tetracyclines 
(WENDLANDT et al., 2013), beta-lactams (LOWY, 2003) aminoglycosides (RAMIREZ; TOLMASKY, 2010) and trimethoprim-sulfamethoxazole (HUOVINEN, 2001) has been previously described. Therefore, the widespread use of antimicrobials in herds could contribute to increased artificial selection pressure on microorganisms, leading to the proliferation of drugresistant subpopulations. This implies a lower cure rate of treated animals and also a serious risk to public health.

Table 3 - In vitro antimicrobial susceptibility profiles of bacterial strains isolated from milk samples collected from cows with mastitis in dairy herds of the Midwest region of Santa Catarina State.

\begin{tabular}{|c|c|c|c|c|c|c|c|c|c|c|c|c|}
\hline & \multicolumn{3}{|c|}{ Staphylococci (\%) } & \multicolumn{3}{|c|}{ Streptococci (\%) } & \multicolumn{3}{|c|}{ Corynebacterium spp. (\%) } & \multicolumn{3}{|c|}{ E. coli $(\%)$} \\
\hline & $\mathrm{S}$ & I & $\mathrm{R}$ & $\mathrm{S}$ & I & $\mathrm{R}$ & $\mathrm{S}$ & I & $\mathrm{R}$ & $\mathrm{S}$ & I & $\mathrm{R}$ \\
\hline AMC & 96.8 & 0.0 & 3.2 & 91.2 & 0.0 & 8.8 & - & - & - & - & - & - \\
\hline AMI & - & - & - & - & - & - & - & - & - & 100.0 & 0.0 & 0.0 \\
\hline AMP & 74.6 & 0.5 & 24.9 & 94.8 & 0.0 & 5.2 & - & - & - & - & - & - \\
\hline CIP & - & - & - & - & - & & - & - & - & 100.0 & 0.0 & 0.0 \\
\hline CLI & 82.2 & 0.0 & 17.8 & 63.8 & 0.0 & 36.2 & 100.0 & 0.0 & 0.0 & 100.0 & 0.0 & 0.0 \\
\hline CNM & 94.8 & 0.0 & 5.2 & 90.9 & 0.0 & 9.1 & - & - & - & 100.0 & 0.0 & 0.0 \\
\hline CPR & 94.8 & 0.0 & 5.2 & 90.9 & 0.0 & 9.1 & - & - & - & 100.0 & 0.0 & 0.0 \\
\hline CRX & 96.9 & 0.0 & 3.1 & 95.7 & 0.0 & 4.3 & - & - & - & 100.0 & 0.0 & 0.0 \\
\hline ERI & - & - & - & 75.7 & 4.3 & 20.0 & - & - & - & 100.0 & 0.0 & 0.0 \\
\hline GEN & 67.0 & 0.0 & 33.0 & - & - & - & 100.0 & 0.0 & 0.0 & 100.0 & 0.0 & 0.0 \\
\hline LVX & - & - & - & - & - & - & - & - & - & 100.0 & 0.0 & 0.0 \\
\hline SUT & 67.8 & 0.0 & 32.2 & - & - & - & - & - & - & - & - & - \\
\hline TET & 61.7 & 0.0 & 38.3 & 59.5 & 0.0 & 40.5 & 14.8 & 0.0 & 85.2 & 100.0 & 0.0 & 0.0 \\
\hline
\end{tabular}

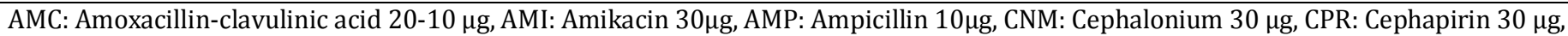

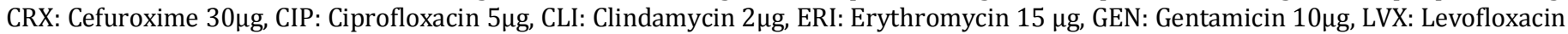

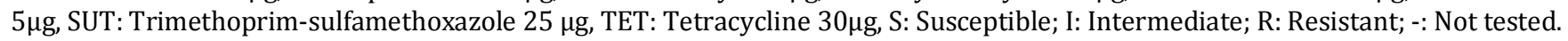

Resistance rates obtained from Staphylococcus strains to tetracycline $(38.3 \%)$ and trimethoprimsulfamethoxazole $(32.2 \%)$ corroborate the results reported in previous studies, in which the resistance rates range from 0 to $76.7 \%$ for tetracycline and 0 to $57.14 \%$ for trimethoprim-sulfamethoxazole (BENGTSSON et al., 2009; COSTA et al., 2013; JAMALI; RADMEHR; ISMAIL, 2014; MARTINI et al., 2017; NERES et al., 2015; ROESCH et al., 2006; SURIYASATHAPORN, 2010). Similar values were found comparing the percentages of resistance to ampicillin $(24.9 \%)$ and gentamicin (33\%) with studies performed abroad, where the values reached $64 \%$ for ampicillin and $100 \%$ for gentamicin (PERSSON; NYMAN; GRÖNLUNDANDERSSON, 2011; ROESCH et al., 2006; SAHEBEKHTIARI et al., 2011; SURIYASATHAPORN, 2010). However, when these values were compared with those obtained in studies conducted in Brazil, it was observed that the rates of resistance to ampicillin were below those observed in previous studies, 39.1\%-95.8\%; while gentamicin resistance was higher, $0-23.1 \%$ (MARTINI et al., 2017; MEDEIROS et al., 2009; NADER FILHO et al., 2007; NERES et al., 2015; OLIVEIRA et al., 2011). This may be due to regional differences in the use of these antimicrobials, producing different selection pressures on bacterial populations or even different genetic characteristics of resistance in strains from different regions, reinforcing the importance of the regional characterization of circulating strains. Aarestrup (2004) points out that information on the occurrence of antimicrobial resistant strains is necessary at the local, regional and international levels in order to detect changes that require differentiated intervention strategies.

Another relevant pathogen causing mastitis is Streptococcus, identified with a frequency of 1.8 to $14 \%$ in Brazilian herds (ANDRADE; HARTMANN; MASSON, 2009; MARTINS et al., 2010; MELLO et al., 2012; OLIVEIRA et al., 2011). In the present study, we found a higher frequency of this pathogen, $34.8 \%$ (Table 02 ), and Streptococcus uberis $(21.7 \%)$ was the predominant species isolated. S. uberis is responsible for a significant proportion of mastitis cases and is considered an environmental pathogen (ABUREEMA et al., 2014; KHAN et al., 2003; UNNERSTAD et al., 2009). Among the risk factors that increase the incidence of $S$. uberis in the herd is the number of lactations. Zadoks et al. (2001) reported that after two lactations, the frequency of isolation of this pathogen in cows increased. A lack of hygiene in the environment has also been attributed as a risk factor for intramammary infections caused by $S$. uberis (TAPONEN et al., 2017). Galton (2004) observed that post-dipping may reduce the risk of intramammary infection by $S$. uberis by up to $94 \%$. In a study conducted in dairy farms of the Midwest and Itajaís High Valley regions in Santa Catarina state, Winck; Neto (2009) observed that postdipping was performed in only $36.1 \%$ of the herds; furthermore, $73.1 \%$ of the farms showed a high total bacterial count (TBC), which indicates deficiencies in hygiene and cleanliness in the milk production.

The highest rates of resistance to streptococci were observed for tetracycline $(40.5 \%)$, clindamycin $(36.2 \%)$ and erythromycin (20\%), corroborating the results 
obtained in previous studies, in which 11.1 to $71.7 \%, 0$ to $61.5 \%$ and 0 to $50 \%$ of Streptococcus isolates were resistant to tetracycline, clindamycin and erythromycin, respectively (DENAMIEL et al., 2005; DUARTE et al., 2004; EBRAHIMI; KHEIRABADI; NIKOOKHAH, 2007; GUÉRIN-FAUBLEÉ et al., 2002; OLIVEIRA et al., 2011; PITKÄLÄ et al., 2007; ROSSITTO et al., 2002).

Other isolated agents were Corynebacterium spp. (7.8\%) and E. coli $(1.4 \%)$. Corynebacterium is a pathogen that is frequently isolated in mastitis cases. In Brazil, the frequency of this agent ranges from 4.8 to $55.2 \%$, while E. coli is isolated sporadically, in 0 to $3.2 \%$ of cases (BRITO et al., 1999; LARANJA; MACHADO, 1994; MARTINS et al., 2010; MELLO et al., 2012; OLIVEIRA et al., 2011). E. coli strains did not show resistance to any of the tested antimicrobials, while for Corynebacterium strains, a high resistance rate to tetracycline (85.2\%) was reported (Table 02). Tetracycline resistance genes in Corynebacterium have been described in the literature (ROBERTS, 2005). However, antimicrobial susceptibility studies in Corynebacterium spp. isolated from mastitis cases are still scarce. Suriyasathaporn et al. (2010) observed that $100 \%$ of Corynebacterium spp. strains were gentamicin resistant, differing significantly from this study $(0 \%)$.

Multiresistance was detected in 53 (27.5\%), 14 (11.7\%), $0(0 \%)$ and $0(0 \%)$ strains of Staphylococcus, Streptococcus, Corynebacterium spp. and E. coli, respectively. Resistance to various antimicrobial drugs results in failures in the standard response to treatment, leading to prolonged disease periods, increased health care expenditures, and risk of death (TANWAR et al., 2014). In addition, it is a public health problem, since bacteria of animal origin can serve as a reservoir of resistance, being transmitted to humans through the consumption of food and through direct or indirect contact with infected animals. Furthermore, antibiotic resistant strains can be disseminated to the environment through animal waste, contributing to the propagation of resistance genes in the environmental microbiome (ECONOMOU; GOUSIA, 2015).

\section{CONCLUSION}

Staphylococci, streptococci and Corynebacterium spp. have great relevance in the etiology of mastitis in dairy herds from the Midwest region of Santa Catarina state. The identification of multiresistant strains in vitro susceptibility profiles to antimicrobials, widely used in the region for the treatment of clinical cases of mastitis, is a warning that underlines the need for the regional characterization of circulating microorganisms, as well as the adoption of prophylactic and control measures.

\section{ACKNOWLEDGEMENTS}

The authors would like to thanks FAPESC for financial support (Chamada Pública 02/2015- T.0. № 2016TR436) and COPÉRDIA's team for collecting the milk samples.

\section{REFERENCES}

AARESTRUP, F.M. Monitoring of antimicrobial resistance among food animals: Principles and limitations. J Vet Med B Infect Dis Vet Public Health, v. 51, n. 8-9, p. 380-388, 2004.

ABEBE, R.; HATIYA, H.; ABERA, M.; MEGERSA, B.; ASMARE, K. Bovine mastitis: prevalence, risk factors and isolation of Staphylococcus aureus in dairy herds at Hawassa milk shed, South Ethiopia. BMC Veterinary Research, v. 12, n. 1, p. 270, 2016.

ABUREEMA, S.; SMOOKER, P.; MALMO, J.; DEIGHTON, M. Molecular epidemiology of recurrent clinical mastitis due to Streptococcus uberis: evidence of both an environmental source and recurring infection with the same strain. J Dairy Sci, v. 97, n. 1, p. 285-290, 2014.

ANDRADE, U. V. C.; HARTMANN, W.; MASSON, M. L. Isolamento microbiológico, contagem de células somáticas e contagem bacteriana total. ARS Vet, v. 25, n. 3, p. 129-135, 2009.

BENGTSSON, B.; UNNERSTAD, H.; EKMAN, E, et al. Antimicrobial susceptibility of udder pathogens from cases of acute clinical mastitis in dairy cows. Vet Microbiol, v. 136, n. 1-2, p. 142-149, 2009.

BRADLEY, A. Bovine mastitis: an evolving disease. Vet J; v. 164, n. 2, p. 116-128, 2002.

BRITO, M.A.V.P.; BRITO, J.R.F.; RIBEIRO, M.T.; VEIGA, V.M.O. Padrão de infecção intramamária em rebanhos leiteiros: exame de todos os quartos mamários de vacas em lactação. Arq Bras Med Vet Zootec, v.51, n. 2, p.129-135, 1999.

CLSI (Clinical \& Laboratory Standards Institute). Performance standards for antimicrobial susceptibility testing; twenty-second informational supplement. CLSI document M100-S22. Wayne, Pennsylvania: CLSI, 2012.184p.

COSTA, G. M. DA; BARROS, R. A.; CUSTÓDIO, D. A. DA C.; et al. Resistência a antimicrobianos em Staphylococcus aureus isolados de mastite em bovinos leiteiros de Minas Gerais, Brasil. Arq Inst Biol, v. 80, n. 3, p. 297-302, 2013.

COSTA KREWER, C. DA; SANTOS AMANSO, E.; VENERONI GOUVEIA, G.; et al. Resistance to antimicrobials and biofilm formation in Staphylococcus spp. isolated from bovine mastitis in the Northeast of Brazil. Trop Anim Health Prod, v. 47, n. 3, p. 511-518, 2015.

DENAMIEL, G.; LLORENTE, P.; CARABELlA, M.; REBUELTO, M.; GENTILINI, E. Anti-microbial susceptibility of Streptococcus spp . isolated from bovine mastitis in Argentina. J Vet Med B, v. 52, n. 3, p. 125-128, 2005.

DIAS, R.V.C. Principais métodos de diagnóstico e controle da mastite bovina. Acta Vet Bras, v.1, p. 23-27, 2007.

DUARTE, R. S.; MIRANDA, P.; BELlEI, B. C.; BRITO, M. A. V. P.; TEIXEIRA, M. Phenotypic and molecular characteristics of Streptococcus agalactiae isolates recovered from milk of dairy cows in Brazil. J Clin Microbiol, v. 42, n. 9, p. 4214-4222, 2004. 
EBRAHIMI, A.; KHEIRABADI, K. H.; NIKOOKHAH, F. Antimicrobial susceptibility of environmental bovine mastitis pathogens in west central Iran. Pak J Biol Sci, v. 10, n. 17, p. 3014-3016, 2007.

ECONOMOU, V.; GOUSIA, P. Agriculture and food animals as a source of antimicrobial-resistant bacteria. Infect Drug Resist, v. 8, n. 1, p. 49-61, 2015.

ERSKINE, R.; CULLOR J.; SCHAELLIBAUM, M.; et al. Bovine mastitis pathogens and trends in resistance to antibacterial drugs. National Mastitis Council Research Committee Report. In: Proceedings of the National Mastitis Council. Verona (WI): National Mastitis Council; p. 400-414, 2004.

ERSKINE, R.J., WALKER, R.D.; BOLIN, C.A. et al. Trends in antibacterial susceptibility of mastitis pathogens during a seven-year period. J Dairy Sci, v. 85, n. 5, p. 1111-1118, 2002.

FREY, Y.; RODRIGUEZ, J. P.; THOMANN, A.; SCHWENDENER, S.; PERRETEN, V. Genetic characterization of antimicrobial resistance in coagulase-negative staphylococci from bovine mastitis milk. J Dairy Sci, v. 96, n. 4, p. 2247-2257, 2013.

GALTON, D. M. Effects of an automatic postmilking teat dipping system on new intramammary infections and iodine in milk. J Dairy Sci, v. 87, n. 1, p. 225-231, 2004.

GUÉRIN-FAUBlEÉ, V.; TARDY, F.; BOUVERON, C.; CARRET, G. Antimicrobial susceptibility of Streptococcus species isolated from clinical mastitis in dairy cows. Int J Antimicrob Agents, v. 19, v. 3, p. 219-226, 2002.

GUIMARÃES, F. F.; JOAQUIM, S. F.; MANZI, M. P.; et al. Comparison phenotypic and genotypic identification of Staphylococcus species isolated from bovine mastitis. Pesqui Vet Bras, v. 36, n. 12, p. 1160$1164,2016$.

HALASA, T.; HUIPJS, K.; OSTERAS, O.; HOGEVEEN, H. Economic effects of bovine mastitis and mastitis management: A review. Vet $\mathbf{Q}, \mathrm{v}$. 29, n. 1; p 18-31, 2007.

HENNEKINNE, J.A.; OSTYN, A.; GUILLIER, F.; HERBIN, S.; PRUFER, A.L.; DRAGACCI, S. How should staphylococcal food poisoning outbreaks be characterized? Toxins, v. 2, v. 8, p. 2106-2116, 2010.

HUOVINEN, P. I. Resistance to Trimethoprim-Sulfamethoxazole. Clin Infect Dis, v. 32, n. 11, p. 1608-1614, 2001.

IBGE. Pesquisa Pecuária Municipal - 2015. Avaliable on: < https://sidra.ibge.gov.br/tabela/74 >. Access on August 2. 2017, 16:30.

JAMALI, H.; RADMEHR, B.; ISMAIL, S. Short communication: prevalence and antibiotic resistance of Staphylococcus aureus isolated from bovine clinical mastitis. J Dairy Sci, v. 97, n. 4, p. 2226-2230, 2014.

KHAN, I.U.; HASSAN, A.A.; ABDULMAWJOOD, A. et al. Identification and epidemiological characterization of Streptococcus uberis isolated from bovine mastitis using conventional and molecular methods. J Dairy Sci, v. 4, n. 3, p.213-224, 2003.

LAFFRANCHI, A.; MULLER, E. E.; FREITAS, J. C. Etiologia das infecções intramamárias em vacas primíparas ao longo dos primeiros quatro meses de lactação. Ciênc Rural, v.31, n.6, p.1027-1032, 2001.

LARANJA, L.F.; MACHADO, P.F. Ocorrência de mastite bovina em fazendas produtoras de leite B no estado de São Paulo. Rev Scientia Agricola, v.51, n.3, p.578-585, 1994

LOWY, F.D. Antimicrobial resistance: The example of Staphylococcus aureus. J. Clin. Invest, v. 111, n. 9, p. 1265-1273, 2003.

MARKEY, B.; LEONARD, F.; ARCHAMBAULT, M.; CULLINANE, A.; MAGUIRE, D. Clinical Veterinary Microbiology. $2^{\text {nd }}$ Edition. Maryland Heights, MO: Mosby Ltd., 2013. 920p.
MARTINI, C. L.; LANGE, C. C.; BRITO, M. A.; et al. Characterisation of penicillin and tetracycline resistance in Staphylococcus aureus isolated from bovine milk samples in Minas Gerais, Brazil. J Dairy Sci, v. 84, v. 2, p. 202-205, 2017.

MARTINS, R. P.; SILVA, J. A. G; NAKAZATO, L.; DUTRA, V.; ALMEIDA FILHO, E. S. Prevalência e etiologia infecciosa da mastite bovina na microrregião de Cuiabá, MT. Ci Anim Bras, Goiânia, v. 11, n. 1, p. 181$187,2010$.

MEDEIROS, E. S.; MOTA, R. A.; SANTOS, M. V.; et al. Perfil de sensibilidade microbiana in vitro de linhagens de Staphylococcus spp. isoladas de vacas com mastite subclínica. Pesqui Vet Bras, v. 29, n. 7, p. 569-574, 2009.

MELLO, P. L.; AGOSTINIS, R. O.; BARZON, E.M.; COLOMBO, R. B.; SILVA, A.V. et al. Prevalência da Mastite Subclínica e Associação dos Agentes Etiológicos com a Contagem de Células Somáticas de Vacas Leiteiras da Região Sudoeste do Paraná. Vet e Zootec, v. 19, n. 4, p. 513-521, 2012.

NADER FILHO, A.; FERREIRA, L. M.; AMARAL, L. A.; JUNIOR, O. D. R.; OLIVEIRA, R. P. Sensibilidade antimicrobiana dos Staphylococcus isolados no leite de vacas com mastite. Arq Inst Biol, v. 74, n. 1, p. 1-4, 2007.

NERES, W. S.; SANTOS, O. M.; TUÑON, G. I. L.; CARNEIRO, M. R. P. Susceptibilidade antimicrobiana de Staphylococcus coagulase positiva isolados de vacas com mastite em Sergipe. Sci Plena, v. 11, p. 11-16, 2015.

OMS. A crescente ameaça da resistência antimicrobiana: opções de ação. Organização Mundial da Saúde: Genebra, Suíça. 2012. 14p.

OLIVEIRA, C. M. C.; SOUSA, M. G. S.; SILVA E SILVA, N. DA; et al. Prevalência e etiologia da mastite bovina na bacia leiteira de Rondon do Pará, estado do Pará. Pesqui Vet Bras, v. 31, n. 2, p. 104-110, 2011.

PERSSON, Y.; NYMAN, A.-K. J.; GRÖNLUND-ANDERSSON, U. Etiology and antimicrobial susceptibility of udder pathogens from cases of subclinical mastitis in dairy cows in Sweden. Acta Vet Scand, v. 53, n. 36, p. 1-8, 2011.

PETROVSKI, K.R.; HEUER, C.; PARKINSON, T.J.; et al. The incidence and aetiology of clinical bovine mastitis on 14 farms in Northland, New Zealand. N Z Vet J, v. 57, n. 2, p.109-115, 2009.

PITKÄLÄ, A.; HAVERI, M.; PYÖLÄLÄRÄ, S.; MYLLYS, V.; HONKANENBUZALSKI, T. Bovine Mastitis in Finland 2001 - Prevalence, Distribution of Bacteria, and Antimicrobial Resistance. J Dairy Sci, v. 87, n. 8, p. 2433-2441, 2004.

RAMIREZ, M.S.; TOLMASKY, M.E. Aminoglycoside modifying enzymes. Drug Resist. Updates, v. 13, n. 6, p. 151-171, 2010.

RIEKERINK, R.G.O.; BARKEMA, H.W.; SCHOLL, D.T.; et al. Management practices associated with the bulk-milk prevalence of Staphylococcus aureus in Canadian dairy farms. Prev Vet Med; v. 97, n.1, p. 20-28, 2010.

ROBERTS, M. C. Update on acquired tetracycline resistance genes. FEMS Microbiol Lett, v. 245, n. 2, p. 195-203, 2005.

ROESCH, M.; PERRETEN, V.; DOHERR, M.G.; et al. Comparison of antibiotic resistance of udder pathogens in dairy cows kept on organic and on conventional farms. J Dairy Sci, v. 89, n. 3, p. 989-997, 2006.

ROSSITTO, P. V; RUIZ, L.; KIKUCHI, Y.; et al. Antibiotic susceptibility patterns for environmental Streptococci isolated from bovine mastitis in central California dairies. J Dairy Sci, v. 85, n. 1, p. 132-138, 2002.

SAHEBEKHTIARI, N.; NOCHI, Z.; ESLAMPOUR, M. A.; et al. Characterization of Staphylococcus aureus strains isolated from raw milk of bovine subclinical mastitis in Tehran and Mashhad. Acta Microbiol Immunol Hung, v. 58, n. 2, p. 113-121, 2011. 
SCHWARZ, S.; SILLEY, P.; SIMJEE, S.; et al. the antimicrobial susceptibility of bacteria obtained from animals. Vet Microbiol, v. 141, n. $1-2$, p. $1-4,2010$.

SOARES, L.C.; et al. Antimicrobial resistance and detection of mecA and blaZ genes in coagulase-negative Staphylococcus isolated from bovine mastitis. Pesqui Vet Bras, v. 32, n. 8, p. 692-696, 2012.

SURIYASATHAPORN, W. Milk quality and antimicrobial resistance against mastitis pathogens after changing from a conventional to an experimentally organic dairy farm. Asian-Australas J Anim Sci, v. 23, n. 5 , p. 659-664, 2010 .

TANWAR, J.; DAS, S.; FATIMA, Z.; HAMEED, S. Multidrug resistance: An emerging crisis. Interdiscip Perspect Infect Dis, v. 2014, p. 1-7, 2014.

TAPONEN, S.; LISKI, E.; HEIKKILÄ, A.-M.; et al. Factors associated with intramammary infection in dairy cows caused by coagulase-negative staphylococci, Staphylococcus aureus, Streptococcus uberis, Streptococcus dysgalactiae, Corynebacterium bovis , or Escherichia coli. J Dairy Sci, v. 100, n. 1, p. 493-503, 2017.

UNNERSTAD, H. E.; LINDBERG, A.; WALLER, K. P.; et al. Microbial aetiology of acute clinical mastitis and agent-specific risk factors. Vet Microbiol, v. 137, n. 1-2, p.90-97, 2009

WENDLANDT, S.; FESSLE, A. T.; MONECKE, S.; et al. The diversity of antimicrobial resistance genes among staphylococci of animal origin. Int J Med Microbiol, v. 303, n. 6-7, p. 338-349, 2013.

WINCK, C. A.; NETO, A. T. Diagnóstico da adequação de propriedades leiteiras em Santa Catarina às normas brasileiras de qualidade do leite. Rev Ciências Agrovet, v. 8, n. 2, p. 164-172, 2009.

$\mathrm{XU}$, J. et al. The diversities of staphylococcal species, virulence and antibiotic resistance genes in the subclinical mastitis milk from a single Chinese cow herd. Microbial Pathog, v. 88, p. 29-38, 2015.

ZADOKS, R. N.; ALLORE, H. G.; BARKEMA, H. W.; SAMPIMON, O. C.; WELLENBERG, G. J.; GRO, Y. T. Cow- and quarter-level risk factors for Streptococcus uberis and Staphylococcus aureus mastitis. J Dairy Sci, v. 84, n. 12, p. 2649-2663, 2001. 